\title{
Thermal comfort and cooling strategies in the Brazilian Amazon. An assessment of the concept of fuel poverty in tropical climates.
}

\author{
Antonella Mazzone ${ }^{1}$
}

\begin{abstract}
Fuel poverty has increasingly been associated with thermal discomfort, health-related issues and winter deaths in the Global North because it can force families to choose between food and a warmer environment. If we juxtapose this concept in the Global South, what can we learn? A recent study shows that between 1.8 and 4.1 billion people, especially in India, Southeast Asia and Sub-Saharan Africa, will need indoor cooling to avoid heat-related health issues, but there are few studies addressing cooling as a fuel poverty issue. This paper aims to address this blind spot in the literature, linking fuel poverty, thermal comfort and cooling strategies in the Brazilian Amazon.
\end{abstract}

This study draws from current definitions and indicators of fuel poverty in the Global North and juxtaposes it in the context of tropical areas to greater understand how fuel poverty affects human health, livelihood strategies and social justice in rural communities in hot climates. To do so, this paper uses qualitative methods and a conceptual framework to guide the analysis. I refer to the right to affordable and sustainable cooling solutions and thermally efficient house materials as 'energy relief'.

Keywords: Thermal Comfort, Fuel Poverty, Cooling Energy, Tropical Climate, Brazilian Amazon

\footnotetext{
${ }^{1}$ A) University of Oxford Smith School of Enterprise and the Environment, South Park Road, Oxford, OX1 3QY, UK; B) Oxford Martin School, University of Oxford, 34 Broad St. Oxford OX1 3BD
} 


\section{Introduction}

2 Commonly referred to as the household's inability to afford sufficient energy to warm

3 the living spaces, fuel poverty has increasingly been identified as a threat to human

4 health. In 2017 alone, 34.000 people died in the UK and Wales because of excessive cold (ONS, 2018). The UK and Europe targeted cold weather mortality rates by adopting fuel poverty strategies. The UK Cold Weather Plan (2018) presented the proposal for long-term strategies focusing on the efficiency of existing infrastructures. However, fuel poverty entails a complex intertwining of factors that go beyond efficiency. For Boardman (1992), the households spending over 10\% of their income on energy bills or switching food for energy were likely to be fuel poor. The inability

11 to pay for electricity/gas bills to warm a house entailed issues beyond the economic 12 axes. Boardman (2013) explains that fuel poverty is also about ensuring affordable fuel 13 prices and building thermal efficiency. Similarly, France used the word 'energy 14 precariousness' in 2010 to define both families' inability to pay for the energy bills, but 15 also those who have 'insufficient resources or housing conditions' (law Grenelle II, $162010)^{\mathrm{i}}$. Despite a lacking common definition, the concept of fuel poverty seems to 17 interlink four major domains: a) household income; b) 'winter deaths'; c) building thermal efficiency; and d) affordable energy provision (as further detailed in Section 2).

20 While the Global North is paving the way for a common understanding of fuel poverty

21 - based on thermal comfort, efficient building materials and energy affordability - little is known about fuel poverty as a heat-related issue in the Global South ${ }^{2}$, especially in those countries where temperatures are consistently hot and humid for most of the year.

24 As well-noted by Fuller at al. (2019: 52), 'Energy poverty debates in the Global South have, in contrast, largely been framed in the context of development, with a specific 26 focus on access to energy and energy security.' The right to afford a cool space in hot 27 weather has largely been ignored in academia and policymaking for decades. Only recently, the topic sparked the attention of policymakers in UN discussions. Mastrucci et al. (2019) found that up to 4.1 billion people need access to indoor cooling

\footnotetext{
${ }^{2}$ For Global South, this paper indicates mainly low to middle-income countries where the climate is mostly hot and humid throughout the whole year.
} 
1 technologies to avoid heat-related stress, especially in India, Southeast Asia and Sub-

2 Saharan Africa. Higher temperatures during summer, the intensity of heatwaves and the

3 length of hot weather in developing countries, as well as major European cities, have

4 re-shifted the focus on the right to afford a cool space for all (Cooling for All, Se4All,

$52019)^{3}$. According to the Seneviratne et al (2012: 112), 'It is very likely that the length,

6 frequency, and/or intensity of warm spells or heat waves will increase over most land

7 areas.' Understanding this issue is timely in light of the increasing number of heat

8 waves hitting most countries in the North and the South in recent years. In Europe, the

9 summer of 2003 caused 70,000 heat-related deaths (WHO, 2004). Similarly, 41,262

10 deaths were linked to the heatwave of 2009 in Russia (Geirinhas et al., 2018), while in

11 the summer of 2015, El Nino took 1,200 and 2,500 in Pakistan and India respectively.

12 Meanwhile, in India, over 40,000 people have suffered heatstroke ${ }^{\text {ii }}$ and dehydration ${ }^{\text {iii }}$

13 and in $2017,4,700^{4}$ deaths were linked to increased temperatures. High temperatures

14 intensify the amount of air pollutants and aeroallergen, which can deteriorate existing

15 respiratory and cardiovascular conditions. In addition, excessive exposure to hot

16 temperatures and sunlight has been found to link to gestational issues and foetus health

17 in pregnant women. A study in rural Bangladesh showed an increase in birth length

18 (Rashid et al., 2016). This evidence was also corroborated by a study conducted in

19 Australia (see Li et al., 2018), as well as Barreca and Schaller (2019), who found that

20 in the US 'exposure to extreme heat causes a large increase in delivery risk. We estimate

21 that birth rates increase by $5 \%$ on days with maximum temperatures above $90{ }^{\circ} \mathrm{F}(32.2$

$\left.22{ }^{\circ} \mathrm{C}\right)$ ' (Barreca and Schaller, 2019: 4). These occurrences are likely magnified in urban

23 areas because of the 'heat-island' effect (Campbell-Lendrum and Corvalán, 2007);

24 however, rural tropical equatorial areas are not exempt from these occurrences. In 2005

25 and 2010, the Amazon forest witnessed two of the most severe droughts in history,

26 which were most likely linked to climate change (Tollefson, 2010). These events caused

27 the loss of biodiversity and the destruction of trees, and severely impacted the lives of

28 remote communities that rely on the river for their livelihoods. In Mato Grosso (Brazil),

29 it was observed that heatwaves are related to an increase in parasitic infections such as

30 dengue and malaria, especially amongst children (Cirino Araújo, 2017). In 2017,

\footnotetext{
${ }^{3}$ See the recently launched programme 'Cooling for All' https://www.seforall.org/interventions/cooling-for-all

${ }^{4}$ https://www.hindustantimes.com/india-news/heatwave-in-india-claim-4-620-lives-in-four-years/storyyDAJTaroKEUBio6uEeTcgN.html Ac-cessed Oc-to-ber 2017
} 
1 Araujo found that the number of children hospitalised during the 2008-2013 heatwave increased from $24 \%$ a $30 \%$ in three main Brazilian states, two of which are located in the Legal Amazon (Mato Grosso and Tocantins). In the Amazon, where the climate is hot and humid for most of the year, adapting to heatwaves can be challenging because of a lack of essential services such as electricity, sanitation and clean water, and health services. Guo et al. $(2017,2018)$ found that Brazil is one of the countries most affected by heatwave-related mortality. Thus, understanding the relationship between heatwaves and health is crucial for better adaptation and mitigation strategies (Meehl and Tebaldi, 2004). As pointed out by Geirinhas et al. (2018), research on the effects of heatwaves in Brazil are scarce, while, to my best knowledge, there are currently no studies addressing this issue in the Brazilian Amazon. Given the increasing recurrences of heatwaves and the magnitude of their impact on health and environment, it is important to address the challenges of sustainable cooling, especially in tropical areas of the Global South. To do so, this paper aims to address the following questions:

To address these questions, this paper selects two case studies in the Brazilian Amazon to represent some of the realities of perennial hot and humid climates in the Global South. As per the nature of qualitative research, case studies may not be representative of all tropical areas in the Global South, but offer an example of fuel poverty and cooling strategies in tropical climates. This paper also emphasises the need to find a conceptual framework to guide energy policies on thermal comfort in tropical areas. The concept of fuel poverty is rarely used by academics in the Global South, while international organisations tend to use the term 'energy poverty' when referring to developing countries. The International Energy Agency (IEA) (2016) defines energy poverty as the lack of modern energy sources (i.e. electricity and diesel) and a reliance on what is available in nature (i.e. biomass and dung). While some institutions, such as

31 the EU Directorate General for Internal Policies, use both terms interchangeably (see 32 Schumacher et al., 2015), this paper keeps the two terms (energy poverty and fuel 33 poverty) separate, interpreting energy poverty as the material and infrastructural lack 
1 of access to energy services. Instead, this paper refers to fuel poverty when energy

2 infrastructures are already available, but households: a) are unable to afford energy services; b) have buildings, which lack thermal-efficient materials and/or passive systems; and c) cannot cope and adapt to heat or cold, as explained in detail in the next section. This paper firstly analyses the current definitions of fuel poverty in the 'North' and then attempts to understand if the same framework can be applied in the 'South' or if new understandings of fuel poverty can emerge from the assessment of different geographies. In order to do so, two recently electrified rural communities in the Brazilian Amazon will be assessed.

\section{2. Understanding fuel poverty in the North}

12 Households spending over $10 \%$ of their income to warm their living spaces were likely 13 to be considered fuel poor (Boardman, 2012). Over time, the concept grew in nuances 14 and also referred to energy efficiency and building materials. Fuel poverty in England 15 is now measured using the Low-Income High Costs (LIHC) indicator, which considers 16 households in fuel poverty 'if they have required fuel costs above average (the national 17 median level) and if they were to spend that amount, they would be left with a residual 18 income below the official poverty line' (Strategy, 2018 p. 6). This indicator refines the 19 economic characterisation of fuel poverty, but it overemphasises the importance of 20 energy efficiency and leaves behind a large portion of the income poor (Middlemiss, 21 2017). Moreover, the new indicator does not capture either fuel market distortions 22 (Middlemiss, 2017), nor the families/individuals who live in thermally inefficient 23 buildings (i.e. big, old houses) but who are not sufficiently 'low-income' to be enrolled 24 in existing schemes that tackle fuel poverty in the UK (e.g. Cold Weather Plan and 25 Warm Home Discounts). For example, the LIHC indicator fails to capture those who 26 have unstable employment, such as zero hour contracts, and those who live in 27 permanent job insecurity.

28 Building or improving a thermally efficient house is not always a matter of relying on 29 the latest technology. Current solutions often underestimate how ancient populations 30 used local materials, architecture and geography for their thermal comfort. In some 
1 parts of Southern Europe, vernacular ${ }^{5}$ architecture is still used to provide thermal

2 comfort and protection from excessive heat (see Basran, 2011; Cardinale et al., 2013;

3 Stefanizzi et al., 2016). Covertino et al. (2017) suggest that in Mediterranean climates,

4 the colour used to paint the houses (e.g. external coating with white lime base) also

5 plays an important role in achieving thermal comfort and in coping with extreme heat

6 (Covertino et al., 2017). Cardinale et al. (2003) also remark on the importance of the

7 study of local climatic conditions and geography to design efficient thermal buildings.

8 With increasing evidence of global warming (see Root et al.,2003; Hughes et al., 2018)

9 and erratic weather conditions, the study of local climatic conditions and weather

10 forecasts can be challenged by new climatic patterns (Guan, 2009).

11 Recently, research is increasingly exploring new metrics to assess individual 12 perceptions of thermal comfort (Wang et al., 2018). Some research has found robust 13 evidence linking fuel poverty and subjective wellbeing (see Churchill et al., 2020); 14 however, little has been found on the link between the subjective and psychological 15 dimensions of being 'fuel poor' and the exposure to harmful weather conditions, 16 especially in the Global South. While fuel poverty has already been associated with 17 winter deaths and health-related conditions, heat deaths are also a matter of fuel 18 poverty. As Hajat et al. (2010 p.856) remarks, 'whereas human adaptation to cold 19 environments is greatly assisted by behavioural responses (e.g. wearing additional 20 layers of clothing), adaptation to heat is dependent on the body's ability to act as a 21 natural cooling system, human beings maintain an internal temperature within a narrow 22 range around $37^{\circ} \mathrm{C}$, and maintain this temperature through sweat production, increased 23 cardiac output, and redirection of blood flow to the skin (increases heat loss by radiation 24 and conduction)' (2010:856).

25 The figure (Figure 1) below illustrates a conceptual framework of the current strategies 26 and themes around fuel poverty, which will be used to assess the same concept for the 27 Amazonian context.

\footnotetext{
${ }^{5}$ Vernacular is a term indicating traditional buildings that have evolved over time, adapting to weather and using local materials (definition in Adenan, 2013).
} 


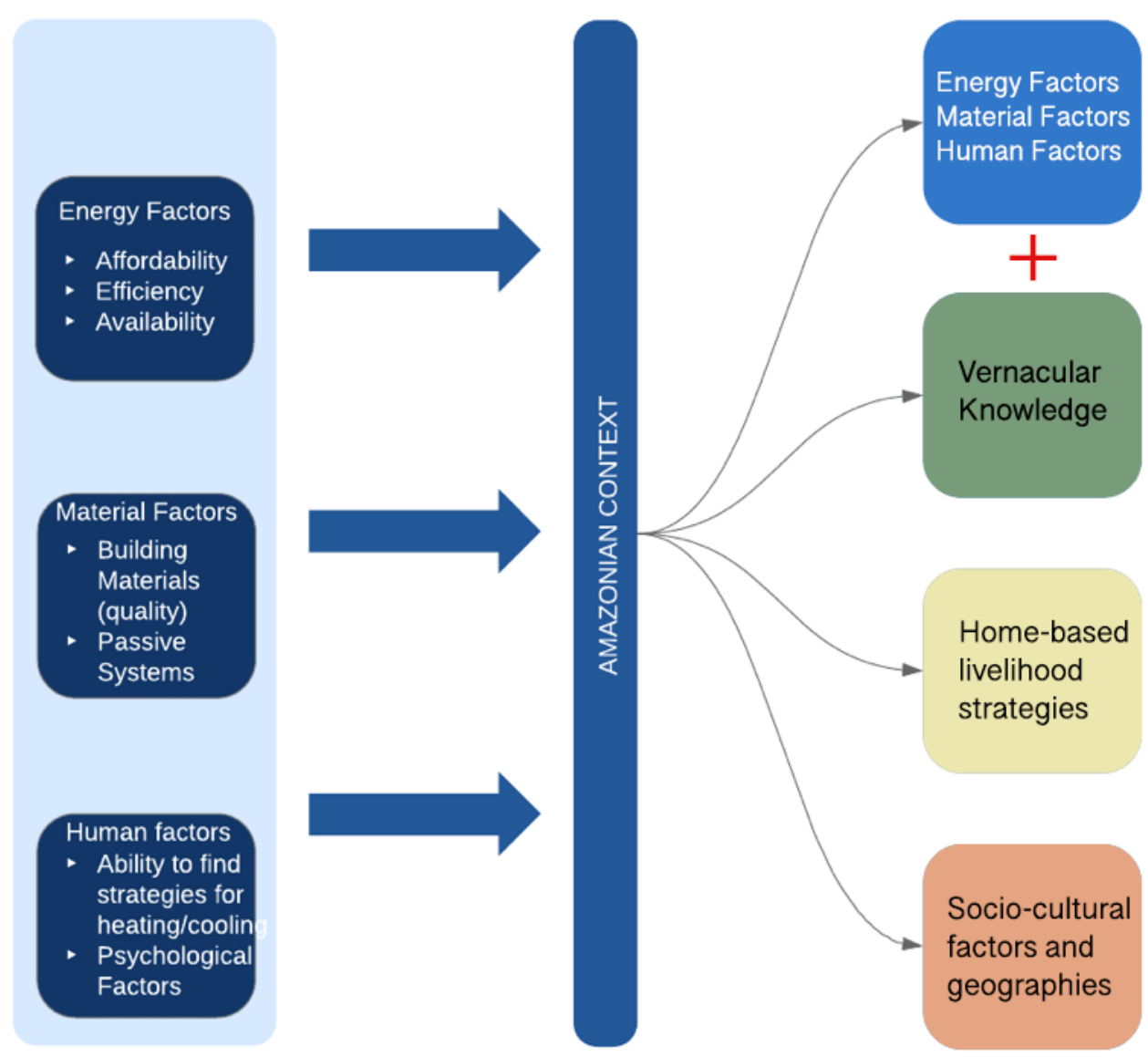

4 The figure shows how, based on a more comprehensive interpretation of fuel poverty,

5 improving building materials and providing adequate and affordable energy are

6 fundamental to human wellbeing and social justice. The question is, can these

7 parameters to analyse fuel poverty be valid in the 'South'? What are the missing pieces?

9 In order to understand the concept of fuel poverty in tropical areas of the Global South, 10 this research will use the case study method. Brazil and the Amazon forest provide a 
1 unique environment for studying the climatic as well as socio-cultural factors related to

2 fuel poverty. Brazil satisfies its national electricity needs prevalently via renewable energy $\left(65.2 \%\right.$ hydraulic energy in 2017) ${ }^{6}$. Through the programme Light for All (2004-2022) ${ }^{\mathrm{iv}}$, Brazil almost reached its universal electricity access goals; however, the Amazonian region is persistently left behind in the universal electrification programme because of socio-economic and environmental reasons (Mazzone, 2019a).

The Brazilian Amazon forest covers an area of 4.1 million $\mathrm{km}^{2}$ across the states of Acre, Amazonas, Roraima, Rondônia, Amapá, Tocantins, Pará and Maranhão. These states (see Figure 2 below) form a socio-economic region legally recognised by the law

11 N124/2007, called Amazônia Legal (Legal Amazon) and corresponding to 61\% of the 12 Brazilian Territory (IBGE, 2019) ${ }^{\mathrm{v}}$. The tropical equatorial climate of the region is hot 13 and humid with average temperatures of $25^{\circ} \mathrm{C}$, which changes throughout the day and 14 at different thermic amplitudes. The case studies chosen for this research are located in 15 the state of Amazonas, which is also Brazil's fourth poorest state and home to $7.1 \%$ of 16 the country's extremely poor (World Bank, 2015). The state of Amazonas covers over $171,559,148,890 \mathrm{~km}^{2}$. Its dense tropical forest expands across $98 \%$ of this territory 18 (Governo do Amazonas, 2017). Mostly isolated from the rest of Brazil, Amazonas has 19 a density of 2,23 habitant per $\mathrm{km}^{2}$. The isolation is due to the dense forest and by the 20 lack of reliable infrastructure, such as roads and highways, which would connect it to 21 the rest of Brazil. Access to the capital of Amazonas State, Manaus, is possible via 22 plane and river. The Amazon Basin is composed of hundreds of tributaries used as waterways for transportation, fishing and travelling by local dwellers. The most 24 important rivers are Rio Negro, Solimoēs, Tapajós and Madeira. The geographical 25 pattern of human settlements is divided into two: riverside communities and inland 26 settlements. Riverside communities can be further divided into lowlands (villages or 27 habitations submerged by the river for half part of the year), upper-land (villages not 28 flooded by the river) and fluctuant villages (residences raised on the river). Inland 29 settlements can instead be found either as isolated communities or at the outskirts of 30 the main towns.

\footnotetext{
${ }^{6}$ According to the National Energy Balance in 2017 Brazil consumed $65.2 \%$ of hydraulic energy; $8.2 \%$ Biomass; $6.9 \%$ of Solar\&Wind power; $2.6 \%$ of Nuclear; $4.1 \%$ Coal and $2.1 \%$ Oil and Derivates. http://www.epe.gov.br/pt/abcdenergia/matriz-energetica-e-eletrica
} 
3 The climate in the Legal Amazon can be defined as hot, super-humid, tropical and

4 equatorial, with annual temperatures of over $26^{\circ} \mathrm{C}$ and up to three months of dry season

5 per year (IBGE, 2002). As shown in Figure 2, the combination of hot temperatures and 6 rainfall of up to $3,100 \mathrm{~mm}$ makes the Legal Amazon the hottest region in Brazil; 7 however, global warming and increased deforestation rates are changing the climate 8 patterns in this area.
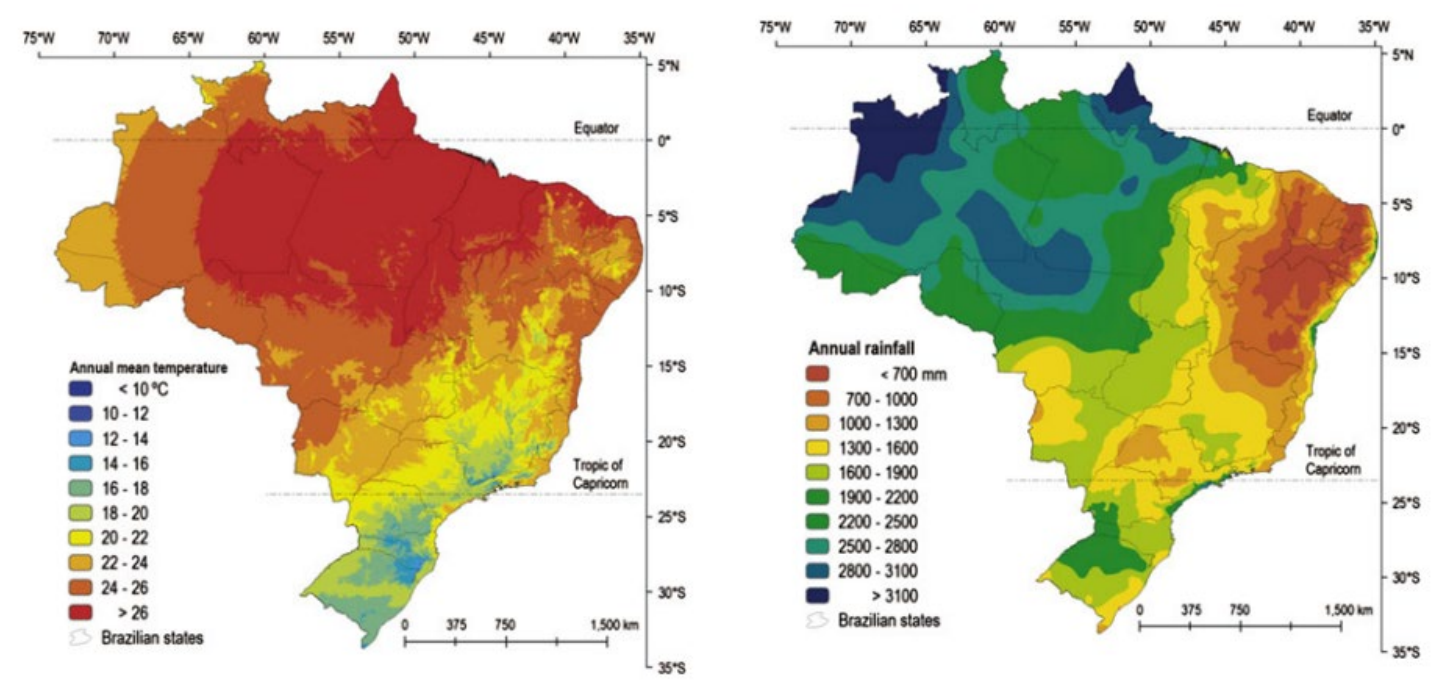

12 According to Nobre et al. (2016), the seasonality of the Amazon rainforest seems to 13 converge towards extreme events (either drought or flood), which 'in the past decade 14 (2005, 2010, and 2015 droughts; 2009 and 2012 floods) have been unusual and may 15 have long-term implications. Global warming is projected to increase the frequency, 16 and even the intensity of extreme events [....]. The dry-season length has been observed 17 to have increased [(6.5 \pm 2.5$)$ days per decade] over southern Amazonia since 1979, 18 primarily owing to a later onset of the wet season and is accompanied by a prolonged 19 fire season' (2016: 10760). This is particularly relevant for local socio-economic 20 activities, wellbeing and human health. A study conducted by Zao et al. (2019), in the 21 major cities in Brazil (including Manaus) for the period 2000-2015, indicates an 22 apparent increase in extremely hot weather and the number of hospitalisations during 
1 those hot days. This indicates that an increase in temperatures due to climate change

2 should not be underestimated in light of its consequences for human health.

\section{3. Methods and methodology}

5 As the aim of this paper is to understand fuel poverty in tropical areas with extreme

6 hot/humid temperatures, the Amazon region offers a perfect landscape to answer this

7 paper's questions. The villages were chosen based on their location and energy systems.

8 Both villages are on-grid via the main thermo-power plant located in the respective

9 municipalities. Key to understanding thermal comfort is the location of these two

10 villages: one is located in-land in an area that has been largely deforested to allow for

11 the production of brickwork. The other is a floating village located on the Amazonian

12 river. Different locations were chosen to better understand and compare the relationship

13 between energy access, thermal comfort and local climate.

\section{The case studies: location and climate}

15 Porta Bela and Jacuru are two fictitious names given to two villages located in the state 16 district of Manacapuru ( $\left.3^{\circ} 17^{\prime} 59^{\prime \prime} \mathrm{S}, 60^{\circ} 37^{\prime} 14^{\prime \prime} \mathrm{W}\right)$ and Iranduba ( $3^{\circ} 17^{\prime} 05^{\prime \prime} \mathrm{S}, 60^{\circ}$ 17 11' 10") respectively, in the State of Amazonas (see Figure 3). The climate is equatorial18 fully humid according to the Koppen-Geiger Climate Classification, and the areas' 19 annual average temperature is $25^{\circ} \mathrm{C}$ (ANA, 2016). Both villages share the same distance 20 from Manaus (roughly $100 \mathrm{~km}$ - straight line distance). Porta Bela is accessible via 21 unpaved roads, while Jacuru is only accessible via boats on the Amazonas River.

FIGURE 3 THE VILLAGES: PORTA BELA AND JACURU

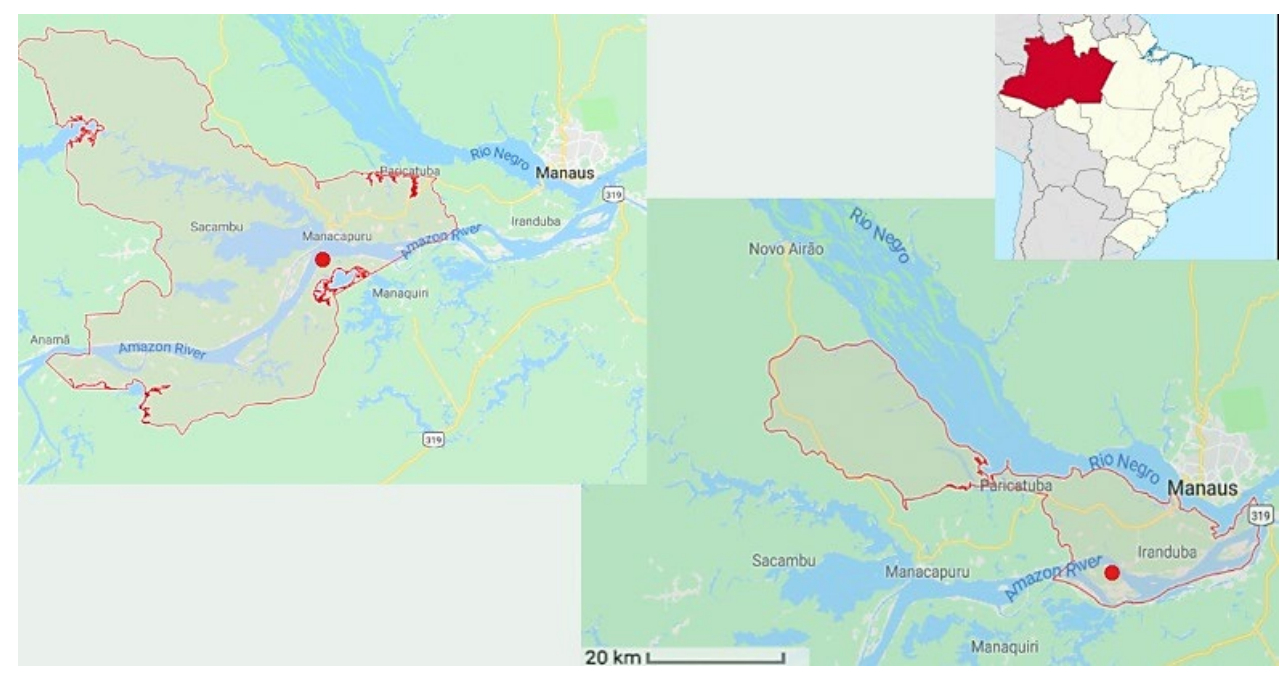


3 Village 1: Porta Bela (Manacapuru)

4 According to the latest census released by the IBGE (2010), the total population of 5 Porta Bela consists of 881 people (54\% women and 46\% men) living in 218 households,

6 with an average of 4.04 people per household. The types of buildings found in the 7 villages are a mix between vernacular architecture (stilt houses made with natural 8 materials, except the roof, which is in aluminium) (see Picture 1). The provision of 9 electricity in this village first occurred in 2005 through the programme Light for All 10 (Luz para Todos), initiated by the energy distribution company, Amazonas Energia. 11 The village was electrified through a grid extension from the city of Manacapuru, which 12 prior 2012 had a mid-size thermopower plant system. Data from Amazonas Energia 13 (2015) indicates that the programme for universal energy access had to retrofit 91 14 consumer units (including households and commercial buildings). The constructions' 15 composition varies between traditional (stilt houses made with wood palm leaves) 16 and traditional-modern (traditional stilt houses mixed with 'modern' materials such as 17 brick or cement and aluminium) (see picture below on the left). All domiciles are self18 built. Roofs made of galvanised steel or aluminium are a common feature in many 19 houses. Asbestos sheets were found in some houses, which is a renowned hazard for 20 human health (see Mathee et al., 2010). Metallic sheets are good heat conductors, yet 21 'are terribly heated even by early morning due to conduction, and it extends for the 22 whole day' (Ponni and Baskar, 2015: 533).
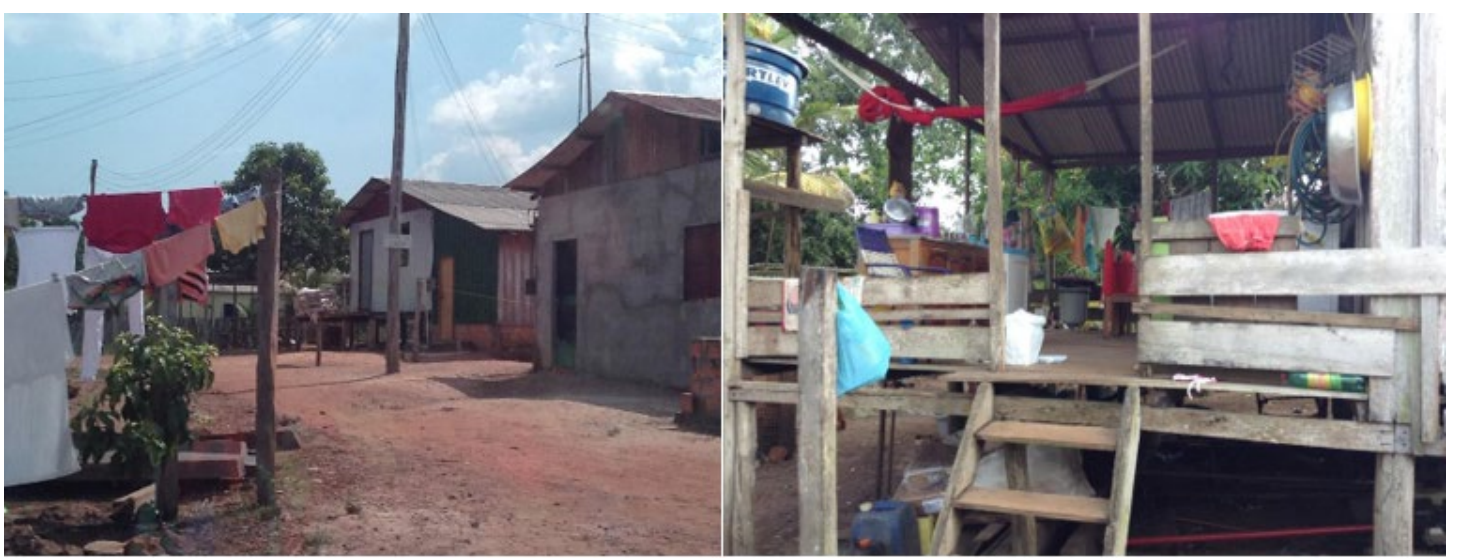

\footnotetext{
${ }^{7}$ For privacy reasons, I cannot expose the exact coordinates of the villages, but the picture shows an approximate location.
} 


\section{Village 2: Jacuru (Iranduba)}

In 2010 , the total population accounted for 266 people, of which $58 \%$ were men and $42 \%$ were women, living in 65 houses, with an average of 4.09 people per household. The village is composed of stilt houses on the river. The village received electricity through a grid extension between 2012 and June 2014. The electrification programme was challenged because the village was raised 'on water' and new in-water electric poles were built, while trees were used as electric poles in some other areas. The village

11 has no sanitation, clean water or waste management. Most of the waste produced by

12 each household is either burnt or disposed of in the river (Amazonas River). Before 13 electrification, only ten houses had an independent small diesel generator for lighting, 14 while the rest lived without electricity. By the end of 2014, 115 consumer units were 15 connected. This shows the number of houses built between 2010 and 2014 doubled. 16 This phenomenon is not new, Mazzone (2019a) found that energy provision generally 17 attracts new residents (living in villages nearby) who are willing to migrate to a village nearby in order to benefit from the energy services.

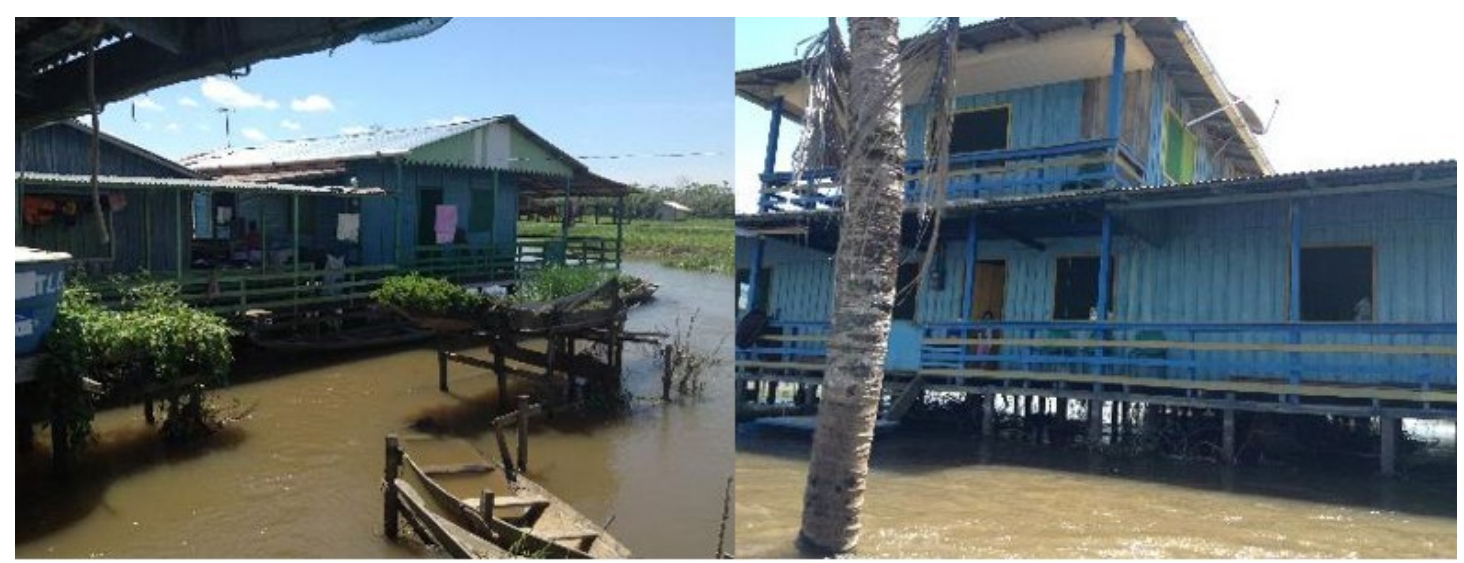

Picture taken by the Author in June 2015 - Iranduba (Amazonas)

24 Picture 2 shows a substantial use of wood for the constructions of the walls, floors and roofs. The latter is used in combination with the usual light aluminium roof. The windows were found permanently open, covered only with a mosquito net. Not closing 
1 the windows is part of one of the cooling strategies aiming to increase natural

2 ventilation and decrease indoors temperatures (see Adenan, 2013). Twelve interviews

3 were collected in Jacuru, while seven were collected in Porta Bela in June and October

42015 respectively. The participants were between 24 and 76 of age. Interviewing people

5 with different socio-demographic characteristics was key to gathering a full picture of

6 the impacts of energy provision and its effect on thermal comfort, and perceiving

7 wellbeing across generations, genders and income. For privacy purposes, the names of

8 the respondents are anonymised and replaced by pseudonyms. Qualitative research is

9 fundamental to gathering in depth data on people's perceptions of wellbeing and

10 changes in daily practices. Interviews were also carried out with Amazonas Energia

11 engineers and technicians, as well as IBGE, in order to assess the 2010 census, which

12 they define as 'setor censitario', and the location on the map, which is otherwise

13 unavailable online for privacy purposes. The table (Table 1) below shows the interviews 14 with rural dwellers.

TABLE 1 METHODS AND QUESTIONS (PRIMARY DATA)

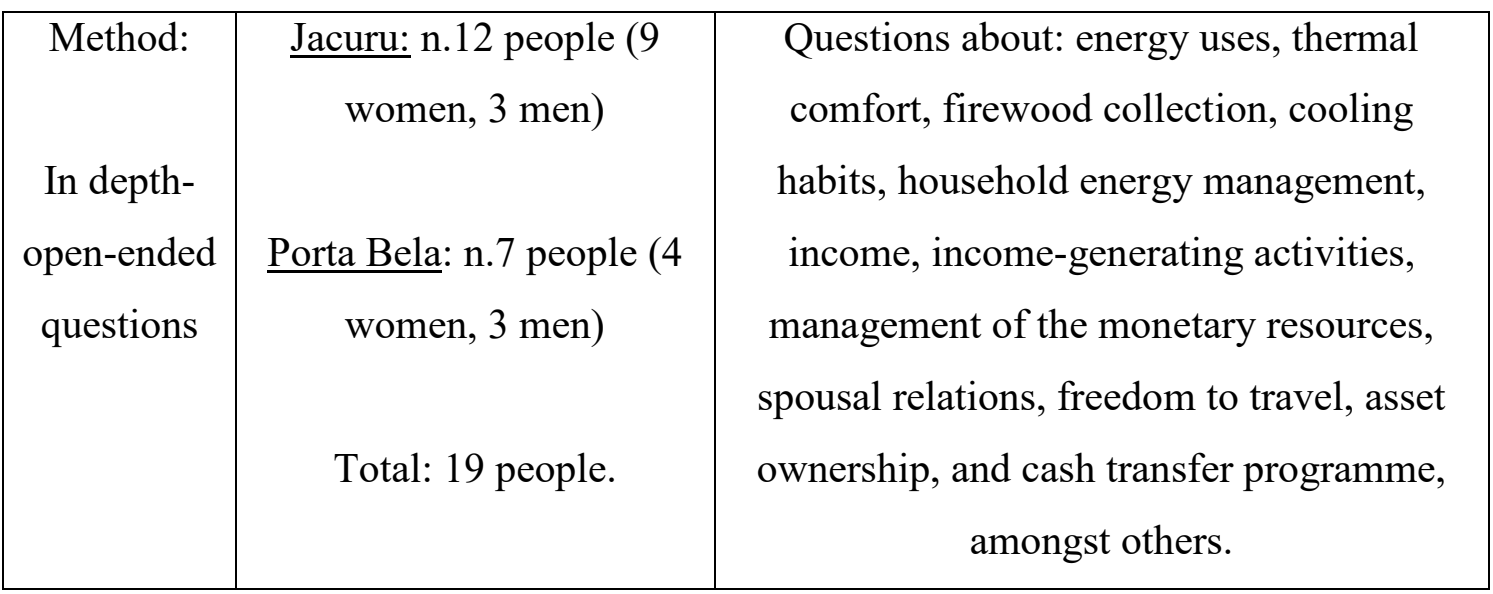

19 Secondary data was assessed before and after the fieldwork. The documents relate to:

20 a) the manual for implementing special projects for energy access in the Amazon, 21 released by the National Electricity Regulator (ANEEL); b) the monthly consumption 22 per consumer unit (or household), released by Eletrobras Amazonas Energia. Census 23 data on the villages was provided in loco at the IBGE's office in Manaus. The database 24 contains anonymised data on the education level and amenities available in the villages, 25 as well as its location on the map. 
2 4. Conceptualising fuel poverty and cooling in rural Amazonian villages

3 In the previous section, the concept of fuel poverty was conceptualised based on several

4 definitions found in the literature of the Global North. A combination of health risks,

5 extreme weather, inefficient building materials, inadequate energy provision and

6 energy affordability are some of the main elements that compose the framework of

7 analysis for fuel poverty. In the subsequent sections, this paper attempts to juxtapose

8 the same concepts used for the Global North and explore the differences found in rural

9 tropical areas.

Building materials and passive systems

11 Vernacular architecture is linked to thermal comfort and energy conservation. In most

12 Amazonian societies, vernacular architecture is already designed to maximise the 13 effects of passive systems for natural cooling. Although the level of humidity in 14 permanent hot equatorial countries tends to reduce the positive effects of passive 15 systems (see Adenan, 2013), vernacular cooling techniques are still considered the most 16 efficient way to cool a space. Among many riverine societies, houses are built on stilts 17 due to seasonal inundation of the vegetation. This design allows cross-ventilation 18 beneath and on top of the dwelling and helps to prevent wild animals' attack. For di 19 Lascio and Barreto et al. (2009), the nearly absent wind speed in the state of Amazonas 20 is caused by an Equatorial Depression and the superficial friction is caused by dense 21 vegetation. Natural ventilation is 'determined by the opening size, wind direction, 22 speed, temperature and humidity of outdoor air entering indoors' (Adenan, 2013: p.4). 23 Amazonian societies have traditionally adapted to living in hot and humid climates via 24 coping strategies such as vernacular buildings (De Paula and Tenorio, 2010). 25 Traditional dwellings in the Amazon can be categorised as stilt houses built with 26 materials found in nature (such as wood, palm straws and natural ropes locally called 27 'cipo'), which guarantees better ventilation. However, the progressive incorporation of 28 new materials such as metal roofs, bricks and ceramic (see Picture 1), together with 29 demographic growth and increasing deforestation rates (especially in Porta Bela), seem 30 to have worsened people's thermal comfort (see section below) and reduced 31 opportunities for using vernacular architectures. Although some studies seem to 32 indicate a better thermal performance of 'modern' buildings versus vernacular 
1 habitations (see Prasetyo et al., 2014), it does not seem to be the case in the studied

2 villages. In spite of a deterioration of indoor ventilation and thermal comfort, people

3 still desire to build a 'modern' home. According to De Paula and Tenorio (2010) this

4 occurs because of the 'desire for a permanent, firm construction. One that suggests

5 eternity (durability)' (2010:1165). The progressive hybridisation of traditional and new

6 materials is culturally charged and driven by social forces, which seem to inspire people

7 to seek ideas of modernity.

8 The adoption of modern materials is also encouraged by the Brazilian housing

9 programme, Minha Casa Minha Vida (My Home, My Life) - a Brazilian Government

10 initiative to tackle the issue of shelter and thermal security in low-income communities

11 or rural and urban areas. The programme launched in 2009 via the Law 11.977/2009

12 and currently offers attractive financing opportunities for low-income groups, rural

13 peasants and traditional groups in order to build a new house or refurbish an existing

14 one in a much 'safer' way, using new materials. Throughout ten years, the programme

15 spent R $\$ 319$ billion on the construction of 4.4 million new habitational units (CAIXA,

16 2019). A crucial characteristic of this programme is its impact on large scale. A single

17 familiar unit cannot request the benefit. To receive the benefit, a minimum of four

18 groups of families, which can be divided into three main groups (by household income)

19 need to contact a local NGO and the municipality to formalise the request. Once all

20 these steps are completed, construction companies initiate the programme (CAIXA, 21 2019). 


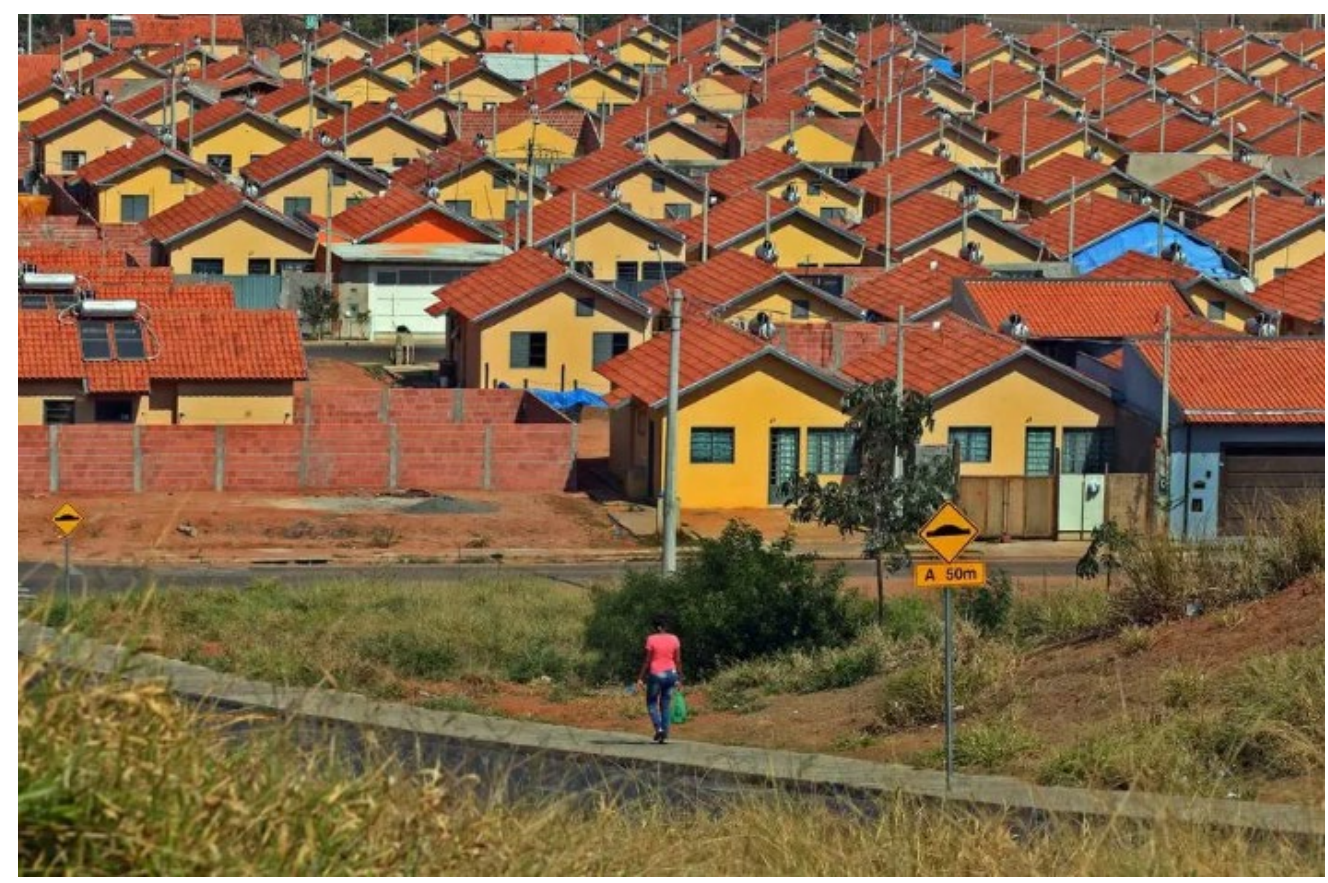

Source: O Estadao, 2019

The programme permanently changes the landscape on a large scale through the standardisation of aesthetics and materials used in the buildings. This paper does not enter in the intricacies of urbanisation issues and the potentially detrimental effects of this measure in terms of segregations (see Hirata, 2009) and deterioration of the local environment. Instead this research highlights the unsuitability of the programme in rural and isolated areas of the Brazilian Amazon because of: a) the material used (which overlooks the use of passive systems and vernacular architecture); b) the geographical locations (riverside communities are likely to be displaced); and c) the disregard of local cultures and customs, as well as socio-cultural diversity. While the programme Minha Casa Minha Vida may build 'safer' dwellings, the new materials (which include bricks, ceramics and metal elements) may not be suitable for the local context and will undoubtedly require the need for artificial cooling systems (see section below), which are not always energy efficient or environmentally sustainable.

\section{Energy un-affordability, poverty and government interventions}

While Brazil has a relatively high price for electricity $(\text { cent } / \mathrm{kWh})^{\mathrm{vi}}$ compared with other upper middle-income countries (Arlet, 2017), it also has a programme to help low- 
1 income families to meet their energy costs. The programme Tarifa Social de Energia

2 Eletrica (Electricity Social Tariff - TSEE), introduced and regulated by the Law

3 n. 12.212/2010 and by the Decree n. 7.583/2011, represents the most critical subsidy for

4 electricity consumption for low-income households. The beneficiaries of the

5 programme must receive up to one minimum wage per month and the discount is

6 applied to the following consumption units.

TABLE 2 ELECTRICITY SOCIAL TARIFF (TSEE)

\begin{tabular}{|c|c|}
\hline Monthly consumption quota (MCQ) & Discount \\
\hline MCQ $<=30 \mathbf{k W h}$ & $65 \%$ \\
\hline $\mathbf{3 0} \mathbf{k W h}<\mathbf{M C Q}<=\mathbf{1 0 0} \mathbf{k W h}$ & $40 \%$ \\
\hline $\mathbf{1 0 0} \mathbf{k W h}<\mathbf{M C Q}<=\mathbf{2 2 0} \mathbf{k W h}$ & $10 \%$ \\
\hline $\mathbf{2 2 0} \mathbf{k W h}<$ MCQ & $0 \%$ \\
\hline
\end{tabular}

Source: ANEEL, 2017

9

10 Traditional communities ${ }^{8}$ (MMA, 2017) connected to the grid and registered in the

11 Federal Government's social programmes are exempt from paying electricity (not 12 exceeding a consumption of $50 \mathrm{kWh} /$ month) (ANEEL, 2017). The figure (Figure 4)

13 below shows the monthly income per capita of the active working population.

\footnotetext{
${ }^{8}$ The Ministry of Environment (MMA) established that, among many traditional groups with distinct livelihood strategies, there are: (Indians, indigenous); Seringueiros (rubber workers), quilombolas (African-Brazilian); Castanheiros (work with Brazilian nuts), Quebradeiras de coco-de-babaçu (coconut workers), Pescadores Artesanais (artisanal fishermen), Ribeirinhos (riverine people), Ciganos (gipsy), and Caatingueiros (living in the biome Caatinga), amongst others (MMA, 2017).
} 
FIGURE 4 POPULATION EARNING LESS THAN 70R\$ PER CAPITA PER MONTH

4 Figure 4 shows that, in the Porta Bela, 67\% of the working population between 15 and 69 of age earns over $70 \mathrm{R} \$(1 / 7 \text { of one minimum wage in } 2010)^{9}$, while $99 \%$ of the working population in Jacuru receives an income below a quarter of the minimum wage. Most of the working population in Jacuru (99\%) is entitled to receive the electricity subsidy compared with $33 \%$ in Porta Bela. This paper will look only at the $99 \%$ of people earning less than 70R \$ in Jacuru, and the 33\% in Porta Bela who earn less than $1 / 7$ of the minimum wage. In 2010, this part of the population was living on US\$1.30 a day. Despite the existence of a social energy tariff for low-income households, people found themselves in energy and economic constraints, which in turn sets favourable ground for improper behaviours, such as electricity thefts. In 2015 , engineer, Ramero (57) asserted that ' $65 \%$ of the population in Jacuru and Porta Bela is benefitting from the energy subsidy [...] however, many steal electricity creating additional connections.' He continued: 'You see? There is no way that a person can put two freezers and an air conditioning here, and still pay nothing! But if you take a look at the household here, they have two freezers and an air conditioner. This is a 'gato' (translation: energy thefts) (Romero, 57, Engineer from Porta Bela, Manacapuru, October 2015). Electricity thefts can be frauds (meter tampering) or illegal connections (Smith, 2004). The issues of electricity theft and the general poor quality of electricity

\section{Section of the population between 15 and 69 of age actively earning}

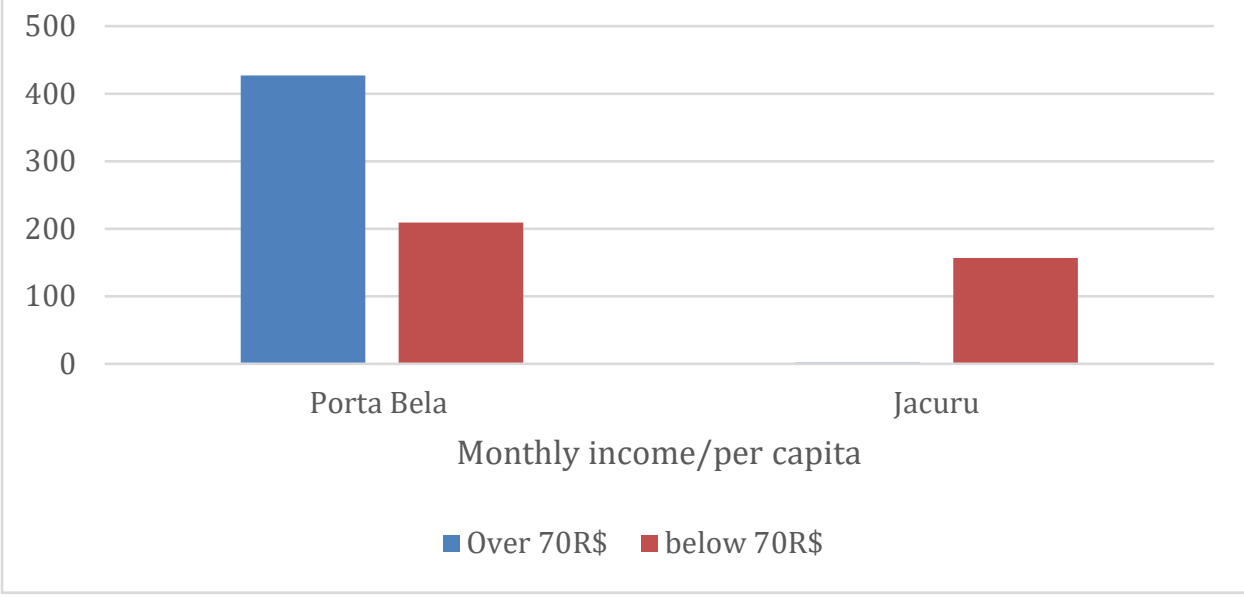

Source: based on IBGE Census 2010 data

\footnotetext{
${ }^{9}$ In 2010, the minimum wage in Brazil was 510R\$ (US\$280.2 exchange rate in 2010: US\$1 $=0.55 \mathrm{R} \$$ )
} 
1 services raised the attention of the World Bank, which implemented several projects to

2 improve the performance of electricity distribution, especially in the Amazonas (World

3 Bank, 2019).

4 Electricity thefts to support high-intensive appliances are a sign of the inability for local 5 people to afford energy (and in particular cooling energy). In many cases, people's 6 desire to satisfy their energy needs goes beyond their personal safety, risking their lives 7 in creating new illegal connections. According to Ramero, engineer, many people die 8 in Porta Bela and Jacuru every year due to electrocution when attempting to make 9 illegal connections from the main power lines and transformers. This is because many power lines have higher voltages than the ones supplying the local residences. The 11 phenomenon of electricity theft is not just an Amazonian reality; according to the 12 Brazilian Agency of Electricity Distributors ABRADEE (2018), between 2007 and 132013 , over 310 people in Brazil died in an attempt to steal electricity, of which $31 \%$ 14 were in North Brazil. The high number of energy theft-related casualties reported each 15 year in Brazil is a clear indication that the government must address the energy needs 16 of the poorest and most marginalised populations.

17 For many of the families living in rural Amazon, owning a freezer has been linked to 18 livelihood diversification and increased income (Mazzone, 2019b). Interviews with 19 Remi (57), the owner of a small spaza shop in Porta Bela, found that during his life, he 20 has attempted to start many businesses (from farming сириаси) to raising cattle, but 21 both activities did not provide enough income. In his words: 'I used to cultivate 22 сириаси, but it didn't work. Then I started to raise 28 cattle, but it didn't work either 23 because it was too expensive [...]. This shop is a whole new thing, totally different! $24[\ldots]$ the main profits come from frozen food and alcohol. Here people like 'geladinha' (iced beer) a lot. Without electricity I wouldn't have this income. Rice and biscuits help as well, but the main profits are mainly frozen food and alcohol' (Remi, 57, Porta Bela, Manacapuru, October 2015).

In this case, cooling technologies play a fundamental role in livelihood strategies and income formation. When Remi, shop owner, was asked why he had an illegal connection, he replied: 'because I cannot afford to pay for the electricity bill. It's too

31 expensive'. This raises some questions on the efficacy of the Brazilian social tariff 32 programme in meeting the needs of the poorest in this area. The programme needs to 
1 consider different cultures, geographies and climates, and tailor subsidies according to

2 the specific needs of the Brazilian region. More temperate climates (as in the case of

3 South Brazil) may have different energy needs for thermal comfort and livelihood

4 strategies. This section shows that energy affordability is also important in diversifying

5 livelihood strategies. This section shows that energy affordability and the availability

6 to diversify livelihood strategies should also be considered in the conceptualisation of

7 a framework for fuel poverty in the Global South.

\section{Exploring different ways to achieve thermal comfort in the Amazon}

9 'Thermal comfort' is the term used to describe a 'satisfactory, stress-free thermal 10 environment in buildings and, therefore, is a socially determined notion defined by 11 norms and expectations' (Nicol and Roaf, 2017). An internationally accepted definition 12 of thermal comfort (used by ASHRAE ${ }^{10}$ ) is 'the condition of mind which expresses 13 satisfaction with the thermal environment' (ISO 7330). Humans have adapted to living 14 in a wide range of climates and temperatures, however, the physical environment has 15 very little input in shaping their idea of comfort. Brager and De Dear (2003) assert that 16 the human's attitude towards comfort is more important than the environment, as a 17 gestalt 'built out of the intersection between objective stimuli with cognitive and 18 emotional processes' (p.179). Okamoto et al. (2017) attempted to bridge the 19 intersection between the objective and the perceived stimuli by experimenting on the 20 effects of temperature, humidity and airflow velocity on brain activity. Despite being 21 subjective, approaches from anthropology and ethnography can be fundamental to understanding the body-matter interactions in the production of thermic wellbeing. An example of body-matter interaction is the case of one of the informants in Jacuru, 24 Jocelina (27); she said: 'I cannot live without the fan, without it I could barely stay on my feet, as I would lay down on the hammock all day. The heat is unbearable.' 26 (Jocelina, 27, Jacuru, Iranduba June 2015). Maria (56) also commented: 'when the 27 energy wasn't working' (before the arrival of the technicians) I would just lay down on 28 the floor all day. Doing nothing and feeling exhausted. For us the most important 29 benefit brought by electricity is cold water [...] a cup of cold water helps a lot in this 30 heat. We were feeling all 'mole' (very weak), the fan and cold water help during the 31 hottest hours' (Maria, 56, Jacuru, Iranduba, June 2015). Another woman, heavily

\footnotetext{
${ }^{10}$ American Society of Heating, Refrigerating and Air-Conditioning Engineers, founded in 1894.
} 
1 pregnant, Estevania (19) said: 'it's so hot in here that the only thing I can do is to lay

2 down on my hammock with the fan on for hours'. To cope with high temperatures,

3 local people tend to bathe in the river (in the case of riverside communities) or 'igarape'

4 (water streams). Bathing practices are very common in the Amazon. The literature on

5 Amerindian populations show a strong connection between cooling practices,

6 pregnancies and water. Rahman (2019) found that among the Warekenas tribe '[...]

7 pregnant women, full-stomached and hot due to the growing accumulation of blood in

8 the womb, bathe early morning when the river is at its coolest. Bathing cools and

9 bolsters them, ensuring they are able to undertake their daily tasks with steadfast

10 industriousness' (Rahman, 2019:65 in Steel and Attala, 2019). These cases of cooling

11 practices and strategies among Amazonian traditional populations reveal some key

12 elements that should be taken into consideration when addressing cooling needs. In

13 both the case of Warekena and Jacuru, people seem to have developed a spiritual

14 'beyond-matter-body divide' connection with the river and the water. Cultural

15 anthropologists can better unpack these relationships and their meanings, which will be

16 the topic of future work. For the purpose of this paper, it suffices to highlight the

17 forgotten element in energy studies; that is people's symbolic interaction with the

18 elements of nature and how it shapes the body and embodied cooling behaviours.

\section{Livelihood strategies}

20 In the study of Mazzone (2019b) in four remote communities in four different districts

21 of Amazonas State, heat-related health issues were found among women and young men cooking with firewood; not only because of the smoke-inhalation but also because of the heat. For example, while in most countries cooking is practised indoors, in the assessed villages, women tend to cook outside their homes, typically during the hottest hours of the day (midday). Heat-related health issues may be exacerbated by performing work during the hottest hours of the day. The accumulation of factors, such as outdoor work, weather (oscillating between $30-37^{\circ} \mathrm{C}$ and $80 \%$ humidity for most of the year (see Horbe, 2013)) and the heat radiated by the firewood oven, is likely to raise body temperatures and cause thermic discomfort. Mota and Souza (2007) report how one of most common livelihood strategies, which is producing and selling manioc flour, is

31 responsible for health-related illnesses in the Amazon. The production of manioc flour 32 has been found to link to thermal discomfort, air pollution and health risks, including 33 burns, heat strokes, persistent sore throats, as well as respiratory issues (see Mota and 
1 Souza, 2007). It is evident that more research is needed to understand the morbidity and

2 mortality rates associated with heat and smoke inhalation during productive and

3 reproductive activities in the Amazon region.

4 Aspiring ideas of 'modernity' are entangled with the necessity of adequate 5 cooling

6 In the previous sections, this paper highlighted how vernacular architecture guarantees

7 better ventilation and thus, better thermal comfort in hot-humid tropical areas.

8 However, the drivers for cooling energy seem to be led not only by the necessity for a

9 more perceived comfortable house, but also by social needs. Sociologists and

10 philosophers like Baudrillard (1970) and Bourdieu (1989) have already identified how

11 the use and purchase of certain products are linked more to social status than a

12 physiological necessity per se (see Picture 4).

PICTURE 4 AIR CONDITIONER IN A VERNACULAR HOUSE

17 The owner of the house, Josualdo (in Picture 4) reported he had to create an illegal

Picture taken by the Author, Porta Bela - Manacapuru (October, 2015) connection (fazer o gato) to use the air conditioner. He also stated that buying the air conditioner was the 'dream of his life': 'I dreamt of having air conditioning in my home since I was a teenager. When I used to go to Manaus and enter those buildings with

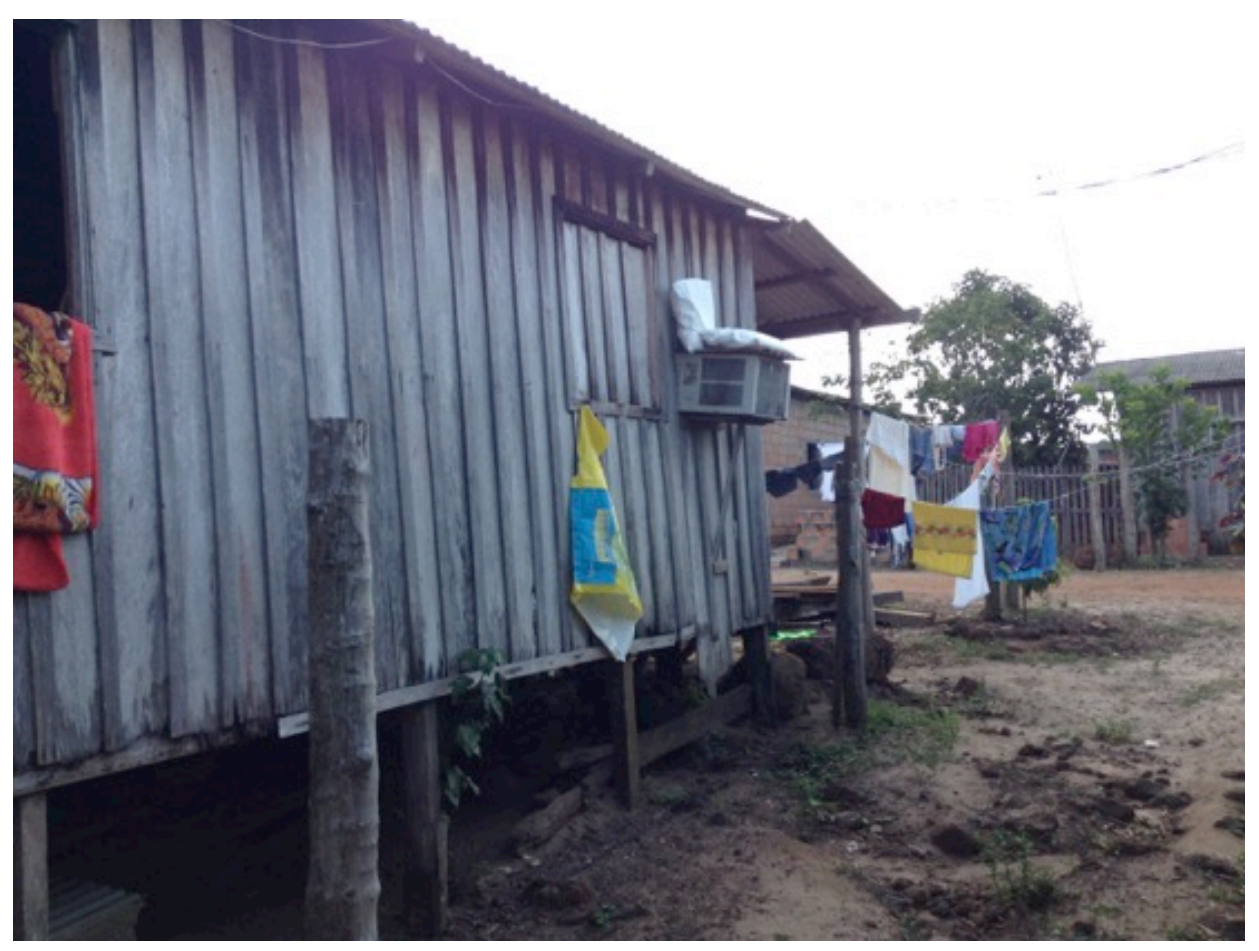


1 aircon, it was a new experience for me. So, when I decided to build this house, I wanted

2 to have air conditioning like the people living in the city' (Josualdo, 47, Porta Bela,

3 Manacapuru, October 2015). In spite of the evident material hybridisation (air

4 conditioner in a traditional dwelling ${ }^{11}$ ), cooling consumption in this region is not only

5 a necessity but also about 'living like people in the city', and therefore people like

6 Josualdo need to satisfy a social image. Social needs and aspirations should be taken in

7 consideration in energy access plans, social housing programmes and fuel poverty

8 strategies. Failure to understand the socio-cultural aspects of energy access and

9 effective building materials can incur in an inefficient use of energy resources and

10 obsolete technology, which is likely to lead to the deterioration of the current climate

11 crisis.

12 5. Conclusion and policy implications

13 This study attempted to understand the socio-cultural and economic implications of fuel 14 poverty and cooling strategies in the rural, tropical areas of Brazil. From the findings, 15 it emerged that the concept of fuel poverty understood in the Global North has shared 16 elements with the case studied in this paper, especially in relation to building materials, 17 household income, energy efficiency, affordability and human physiological strategies. 18 However, new nuances can be found to help develop a new conceptual framework for 19 fuel poverty in tropical areas of the Global South, namely: a) home-based livelihood 20 strategies; b) socio-cultural elements; and c) vernacular architecture. In many rural 21 areas of the Brazilian Amazon, residential energy services are also used to diversify 22 local livelihood strategies (see Mazzone 2019a). Energy for productive needs in the 23 residential sector should also be part of the fuel poverty discourse in the Global South, 24 as for many people living in poverty, energy can be the only opportunity to escape the 25 poverty trap. Energy for home-based businesses should perhaps be considered in a further understanding of fuel poverty in the most industrialised countries.

27 Another element that should be taken in consideration in the framework for fuel poverty 28 in the Global South is role of passive systems and vernacular knowledge. In the case 29 studies examined, most of the assessed dwellings were built according to vernacular 30 techniques, which were supposed to provide effective passive systems. However, the

\footnotetext{
${ }^{11}$ Picture 4 shows how the material of the traditional dwelling does not insulate the circulation of cooling air. Fissures and cavities in the wood create an inefficient use of air conditioning. Because of Jousaldo's low income, he owned a second-handed, energy-intensive and inefficient air conditioner.
} 
1 progressive hybridisation of modern materials driven by people's desire for new

2 building materials (metal roofs and cement) as elements of housing is creating new

3 challenges for efficient passive systems and natural cooling. As per the case of Porta

4 Bela, new materials contribute to nullifying the natural cooling systems of traditional

5 Amazonian dwellings, worsening people's perceived thermal comfort. Meanwhile, in

6 Jacuru, the number of stilt houses built with natural materials outnumbered hybrid ones.

7 As a result, the use of active cooling in Jacuru was significantly lower than in Porta

8 Bela. While vernacular architecture can be an effective measure to curb the raising

9 demand for unsustainable active cooling in hot countries, it seems largely ignored in

10 the Global North, which focuses on tackling winter deaths and thermal discomfort. This

11 paper suggests that vernacular strategies and vernacular architecture tend to be an

12 effective measure for thermal comfort in the Global South, hence why they are largely

13 absent in energy scholarship and national policies in the Global North. Vernacular

14 'warming' could potentially be useful to tackle fuel poverty and thermal comfort in cold 15 climates; more research is needed to understand its applications.

16 Thermal comfort and livelihood strategies are not the only drivers for household energy 17 services in the cases studied. Social factors, such as exposure to air conditioning, human 18 aspirations, tourism, migrations and social status, to name a few, are also important 19 drivers for cooling services. The social drivers for cooling energy can be as important 20 as the need to satisfy a physiological need of thermal comfort, to the extent that people 21 risk their lives when creating illegal electricity connections. Despite the efforts of the 22 government to launch social tariff programmes (Tarifa Social), an energy subsidy is not 23 sufficient in satisfying the 'social' cooling needs of the poorest.

24 Fuel poverty in the Global North is not only a matter of improving building insulation 25 and energy efficiency, but also improving the choice of appropriate materials, which 26 should match local cultures. In Brazil, programmes designed to guarantee comfort, 27 shelter and energy security for low-income families (see Minha Casa Minha Vida and 28 Tarifa Social) are failing to consider different cultures, geographies and livelihood 29 strategies, resulting in the exacerbation of indoor temperatures and electricity thefts. 30 Welfare measures (such as energy social tariffs and Minha Casa Minha Vida) should 31 be reassessed and re-tailored in light of the different regional climates. 
1 Given the increasing threat of rising temperatures and heatwaves in Brazil, and in the

2 Amazon (Cirino Araujo, 2017), this paper suggests that sustainable cooling

3 technologies, together with a deeper understanding of how vernacular building

4 materials can ensure thermal comfort, is fundamental for health and wellbeing in

5 tropical-humid-hot areas. This paper found that in the Amazon, current strategies to

6 produce the local staple food (farinha) are endangering local people's health and their

7 thermal comfort. Further studies are needed to curb the multiple threats to human health

8 (the mix between hot temperature and smoke inhalation) in the Brazilian Amazon.

9 Tackling thermal comfort and fuel poverty in the Amazon is particularly complex, as it

10 should consider multiple factors, such as vernacular knowledge and natural materials,

11 local cultures, targeted social policies, and new desires feeding specific ideas of

12 'modernisation' in certain groups. Failure to consider the importance of energy relief

13 in the Amazon, and other tropical regions of the Global South, may perpetuate the swift

14 adoption of inefficient active cooling; energy thefts and related casualties, heat-stress

15 and heat-related morbidity; and environmental degradation on a large scale.

\section{Further considerations}

18 Essential for this research is the concept of subjective thermal adaptability, which 19 comprehends an ever-changing subjective adaptation to different temperatures.

20 Subjective thermal adaptation is a complex concept, bringing together notions of 21 physical perception of temperatures, culture and aspiring desires. Tackling how people 22 change their subjective thermal adaptation is key to designing future energy policies. 23 The list below summarises the finding of this research and suggests future research:

a) Amazonian villages are not culturally, socially or ethnically homogeneous. This brings a differentiated pool of people with different needs, energy uses and preferences, incomes, and differentiated personal adaptability to high temperatures.

b) Land occupations and rural-rural or urban-rural migrations help to maintain the continuous heterogeneity of the social and cultural composition of villages. 
c) Cultural diversity and exposure to non-traditional buildings introduce new materials, which are often not suitable for the local weather.

d) Social status (owning an air conditioner or other cooling technologies is a social symbol for wealth and power). Social factors influence the choice of housing materials and technology chosen to cool indoor temperatures. Further studies are needed to explore the socio-cultural and behavioural component driving the demand for active cooling technologies.

e) Further studies on thermo-conductivity of building materials are needed in the Amazon in order to assess the best strategies that ensure thermal comfort and cooling temperatures.

\section{Acknowledgements}

I would like to thank King's College London for funding this research as part of my doctoral project. My gratitude also goes to 'Dona Agda' and Senhor Carlos for guiding me in the Amazon forest.

\section{(1)}

\section{References}

Adenan H., R., 2013. Passive Cooling For Houses On Water In Brunei Darussalam. Search For A New Vernacular. PLEA2013 - 29th Conference, Sustainable Architecture for a Renewable Future, Munich, Germany 10-12 September 2013

Agência Nacional de Águas (ANA), 2016. Mudanças Climáticas e Recursos Hídricos: avaliações e diretrizes para adaptação. Mudanças Climáticas e Recursos Hídricos.

Agência Nacional de Energia Elétrica (ANEEL), 2017. Ofício Circular nº 0010/2017-

SRD/ANEEL. Ministério de Minas e Energia, 10. Retrieved from 
1 http://www.aneel.gov.br/documents/656827/15234696/OficioCircular 10-

$2 \quad 2017 / 366 \mathrm{f} 48 \mathrm{db}-36 \mathrm{a} 9-3 \mathrm{~d} 57-0 \mathrm{eac}-4 \mathrm{ab} 7 \mathrm{e} 4012 \mathrm{cfb}$

3 Alvares, C.A., Stape, J.L., ... Sparovek, G., 2013. Köppen's climate classification map

4 for Brazil. Meteorologische Zeitschrift 22, 711-728. doi:10.1127/0941-

$5 \quad 2948 / 2013 / 0507$

6 Annual Fuel Poverty Statistics report, 2018 (2016 data). Department for Business,

$7 \quad$ Energy and Industrial Strategy. England.

8 https://assets.publishing.service.gov.uk/government/uploads/system/uploads/attachme

9 nt data/file/719106/Fuel_Poverty_Statistics Report 2018.pdf

10 Arlet, J. 2017. Electricity Tariffs, Power Outages and Firm Performance: A

11 comparative Analysis. Global Indicators Group, Development Economics. The World

12 Bank. March 2017. Available Online:

13 http://pubdocs.worldbank.org/en/444681490076354657/Electricity-Tariffs-Power-

14 Outages-and-Firm-Performance.pdf

15 Associacao Brasileira de Distribudores de Energia Eletrica (ABRADEE), 2018.

16 Número de mortes por contato com a rede elétrica aumenta no Brasil e Amazonas

17 Energia alerta sobre cuidados com a rede elétrica que podem salvar vidas. Available

18 online: https://www.abradee.org.br/numero-de-mortes-por-contato-com-a-rede-

19 eletrica-aumenta-no-brasil-e-amazonas-energia-alerta-sobre-cuidados-com-a-rede-

20 eletrica-que-podem-salvar-vidas/

21 Başaran, T., 2011. Thermal analysis of the domed vernacular houses of Harran,

22 Turkey. Indoor and Built Environment 20, 543-554. doi:10.1177/1420326X11411237

23 Barreca, A., Schaller, J. 2019. The impact of high ambient temperatures on delivery

24 timing and gestational lengths. Nat. Clim. Chang. doi:10.1038/s41558-019-0632-4

25 Baudrillard, J., 2017. The Consumer Society: Myths and Structures, The Consumer

26 Society: Myths and Structures. SAGE Publications Ltd. doi:10.4135/9781526401502

27 Brager G.S and de Dear R. 2003. Historical and Cultural Influences on Comfort

28 Expectations. Ch.11. in Buildings, Culture and Environment. Edit. Cole R.J. Lorch, R.

29 2003, Blackwell Publishing 
1 Boardman, B., 2012. Fuel poverty synthesis: Lessons learnt, actions needed. Energy

2 Policy 49. doi:https://doi.org/10.1016/j.enpol.2012.02.035.

3 Boardman, B., 2013. Fixing fuel poverty: Challenges and solutions. Fixing Fuel

4 Poverty: Challenges and Solutions (pp. 1-244). Taylor and Francis.

$5 \quad$ https://doi.org/10.4324/9781849774482

6 Bourdieu, P., 1989. Social Space and Symbolic Power. Sociological Theory 7, 14.

7 doi: $10.2307 / 202060$

8 Campbell-Lendrum, D. and Corvalán, C., 2007. Climate change and developing-

9 country cities: implications for environmental health and equity. Journal of Urban

10 Health, 84(1), pp.109-117.

11 CAIXA, 2019 Minha Casa Minha Vida Mais que mudar de endereço, é mudar de

12 vida. Available online: http://www.caixa.gov.br/voce/habitacao/minha-casa-minha-

$13 \underline{\text { vida/Paginas/default.aspx }}$ Accessed on the 20/07/2019

14 Cardinale, N., Ruggiero, F., 2000. Energetic aspects of bioclimatic buildings in the

15 Mediterranean area: A comparison between two different computation methods.

16 Energy and Buildings 31, 55-63. doi:10.1016/S0378-7788(99)00005-5

17 Cardinale, N., Micucci, M., \& Ruggiero, F., 2003. Analysis of energy saving using

18 natural ventilation in a traditional Italian building. Energy and Buildings, 35(2), $153-$

19 159. https://doi.org/10.1016/S0378-7788(02)00024-5

20 Cardinale, N., Rospi, G., Stefanizzi, P., 2013. Energy and microclimatic performance

21 of Mediterranean vernacular buildings: The Sassi district of Matera and the Trulli

22 district of Alberobello. Building and Environment 59, 590-598.

23 doi:10.1016/j.buildenv.2012.10.006

24 Churchill, A., Smyth, R., Farrell, L., 2020. Fuel poverty and subjective wellbeing.

25 Energy Economics 86 (104650). doi:https://doi.org/10.1016/j.eneco.2019.104650.

26 Cirino Araújo P.H, 2017. 'Ensaios econômicos sobre ondas de calor e seus impactos

27 sobre a saúde no Brasil; Economic essays on heatwaves and their impacts on health in

28 Brazil http://lattes.cnpq.br/5611371794712864 URI:

29 http://www.locus.ufv.br/handle/123456789/10586 
1 Convertino, F., Di Turi, S., Stefanizzi, P., 2017. The color in the vernacular

2 bioclimatic architecture in Mediterranean region, in: Energy Procedia. Elsevier Ltd,

3 pp. 211-218. doi:10.1016/j.egypro.2017.08.142

4 di Lascio, Barreto, 2009. Energia e desenvolvimento sustentável para a Amazônia

5 rural brasileira : eletrificação de comunidades isoladas / Marco Alfredo Di Lascio,

6 Eduardo José Fagundes Barreto; com a colaboração, Daniel Pioch, Écio Rodrigues.

7 Brasília : Ministério de Minas e Energia, 2009. ISBN 978-85-62491-00-9. Ministério

8 de Minas e Energia.

9 De Paula A.K.N and Tenorio, R. 2010 Ribeirinhos: a sustainability assessment of

10 Housing typologies in the Amazon Region. World Academy of Science, Engineering

11 and technology 242010

12 Geirinhas, J. L., Trigo, R. M., Libonati, R., Coelho, C. A. S., \& Palmeira, A. C. 2018.

13 Climatic and synoptic characterization of heat waves in Brazil. International Journal

14 of Climatology, 38(4), 1760-1776. https://doi.org/10.1002/joc.5294

15 Governo do Amazonas. 2017. Dados. http://www.amazonas.am.gov.br/o-

16 amazonas/dados/

17 Guan, L., 2009. Preparation of future weather data to study the impact of climate

18 change on buildings. Building and Environment, 44(4), 793-800.

19 https://doi.org/10.1016/j.buildenv.2008.05.021

20 Guo, Y., Gasparrini, A., Li, S., Sera, F., Vicedo-Cabrera, A. M., de Sousa Zanotti

21 Stagliorio Coelho, M., ... Tong, S., 2018. Quantifying excess deaths related to

22 heatwaves under climate change scenarios: A multicountry time series modelling

23 study. PLOS Medicine, 15(7), e1002629.

24 https://doi.org/10.1371/journal.pmed.1002629

25 Guo, Y., Gasparrini, A., Armstrong, B. G., Tawatsupa, B., Tobias, A., Lavigne,

26 E.,Tong, S., 2017. Heat wave and mortality: A multicountry, multicommunity

27 study. Environmental Health Perspectives, 125(8). https://doi.org/10.1289/EHP1026

28 Hajat, S., O'Connor, M. and Kosatsky, T., 2010. Health effects of hot weather: from

29 awareness of risk factors to effective health protection. The Lancet, 375(9717),

30 pp.856-863. 
1 Hirata F., 2009 "Minha Casa, Minha Vida": Política habitacional e de geração de

2 emprego ou aprofundamento da segregação urbana? Revista Aurora, Universidade de

3 Sao Paulo

4 Horbe, C. 2013. Geoquímica de rios de água preta do sudeste do Amazonas: Origem,

5 fluxo dos elementos e consumo de CO2. Acta Amazonica, 43(3), 343-352.

6 https://doi.org/10.1590/S0044-59672013000300010

7 Hughes, T. P., Kerry, J. T., Baird, A. H., Connolly, S. R., Dietzel, A., Eakin, C. M.,

8 Torda, G. 2018. Global warming transforms coral reef

9 assemblages. Nature, 556(7702), 492-496. https://doi.org/10.1038/s41586-018-0041102

11 IBGE, Synopsis of the 2010. Demographic

12 Census. https://censo2010.ibge.gov.br/sinopse/index.php?dados=P13\&uf $=00$

13 IEA 2016. International Energy

14 Agency https://www.iea.org/media/weowebsite/energymodel/Poverty Methodology.p $15 \underline{\mathrm{df}}$

16 FINEP - Ministério Da Ciência E Tecnologia Financiadora De Estudos E Projetos 17 2008- Relatorio de Gestao Finep 2008

18 https://www.mctic.gov.br/mctic/export/sites/institucional/backend/galeria/arquivos/20

19 17/08/10/Rel_Gestao_2008.pdf

20 Fuller, S., Barber, L. B., \& Mah, D. N. yin. (2019). Narratives of energy poverty in 21 Hong Kong. Energy and Buildings, 191, 52-58.

22 https://doi.org/10.1016/j.enbuild.2019.03.015Li, S., Wang, J., ... Tong, S., 2018.

23 Exploring associations of maternal exposure to ambient temperature with duration of 24 gestation and birth weight: A prospective study. BMC Pregnancy and Childbirth 18. 25 doi:10.1186/s12884-018-2100-y

26 Liddell, C., Morris, C., Gray, B., Czerwinska, A., \& Thomas, B. 2016. Excess winter 27 mortality associated with Alzheimer's Disease and related dementias in the UK: A 28 case for energy justice. Energy Research \& Social Science, 11, 256-262.

29 https://doi.org/10.1016/j.erss.2015.11.007 
1 Mastrucci A, Byers E, Pachauri S, Rao ND. 2019. Improving the SDG energy poverty targets: residential cooling needs in the Global South. Energy \& Buildings [pure.iiasa.ac.at/id/eprint/15739]

4 Mathee, A., Oba, J., Rose, A., 2010. Climate change impacts on working people (the HOTHAPS initiative): findings of the South African pilot study. Global Health Action 3, 5612. doi:10.3402/gha.v3i0.5612

Mazzone, A., 2019a. Decentralised energy systems and sustainable livelihoods, what are the links? Evidence from two isolated villages of the Brazilian Amazon. Energy

Mazzone, A., 2019b. Energy transitions in rural Amazonia: the implications of

11 energy availability for income diversification and gender relations. Thesis awarded 01/04/2019 by King's College London, London, UK

13 Middlemiss, L. (2017). A critical analysis of the new politics of fuel poverty in

14 England. Critical Social Policy, 37(3), 425-443. https://doi.org/10.1177/0261018316674851 Ministerio de Minas e Energia (MME), 2013. Impactos do Programa Luz para Todos 17 Pesquisa de Satisfação 2013. Available Online:

18 https://www.mme.gov.br/luzparatodos/downloads/pesquisa_de_satisfacao_2013.pdf

19 MMA, 2017. In: Arranjos produtivos locais : APLs de produtos da

20 sociobiodiversidade / Ministério do Meio Ambiente - Brasília, DF: MMA, 2017.

21 ISBN: 978-85-7738-350-4. Ministerio do Meio Ambiente., Brasilia.

22 Mota, S., Souza, C, 2007. Inovação tecnológica e melhorias no design do forno da 23 casa de farinha/ ENEGEP.

24 https://www.cdeam.ufam.edu.br/images/Publicacoes_e artigos/2007/2007_Art_2_CD 25 EAM.pdf

26 Nicol, J. F., \& Roaf, S. 2017. Rethinking thermal comfort. Building Research and Information, 45(7), 711-716. https://doi.org/10.1080/09613218.2017.1301698

28 Nobre, C., et al., 2016. Land-use and climate change risks in the Amazon and the 29 need of a novel sustainable development paradigm. PNAS doi:https://doi.org/10.1073/pnas.1605516113. 
1 Meehl, G. A., \& Tebaldi, C. 2004. More intense, more frequent, and longer lasting

2 heat waves in the 21st century. Science, 305(5686), 994-997.

3 https://doi.org/10.1126/science.1098704

4 O Estadao, 2019. Quase 50\% das casas do Minha Casa Minha Vida têm falhas de construção available online: https://economia.estadao.com.br/noticias/geral,quase-50-

6 das-casas-do-minha-casa-minha-minha-vida-tem-falhas-de-construcao,70001654211

7 Accessed on the 20/07/2019

8 Okamoto, T., Tamura, K., ... Futaeda, T., 2017. Physiological activity in calm thermal 9 indoor environments. Scientific Reports 7. doi:10.1038/s41598-017-11755-3

10 Office for National Statistics (ONS). 2018. England and Wales Excessive Winter

11 Deaths in England and Wales

12

13 Prasetyo, Y.H., Alfata, M.N.F., Pasaribu, A.R., 2014. Typology of Malay Traditional

14 House Rumah Lontiok and its Response to the Thermal Environment. Procedia

15 Environmental Sciences 20, 162-171. doi:10.1016/j.proenv.2014.03.022

16

Ponni, M., Baskar, R., 2015. Comparative study of different types of roof and indoor temperatures in tropical climate. International Journal of Engineering and Technology 7, 530-536.

Public Health England NHS. 2018 The Cold Weather Plan for England Protecting health and reducing harm from cold weather. Department of Health Guidance.

Rahman Elizabeth, 2019. Cooled, Cured and Sedimented. Reforming and Edifying the Hydrocentric Infants of North-western Amazonia. In Steel, L. \& Attala, L., 2019. Body matters: exploring the materiality of the human body.

Rashid, H., Kagami, M., ... Wagatsuma, Y., 2016. Temperature during pregnancy influences the fetal growth and birth size. Tropical Medicine and Health 45. doi:10.1186/s41182-016-0041-6

Reis Filho, M. M. 2012. 'O lugar do trabalho de mulheres e homens em Izidoro eBarro Alto'. In: Torres, Iraildes Caldas (Org.). O ethos das mulheres da floresta. Manaus: Editora Valer/Fapeam, Brazil. 
1 Root, T., Price, J., Hall, K., \& Schneider, S., 2003. Fingerprints of global warming on

2 wild animals and plants. Nature, 421(6918), 57-60.

3 https://doi.org/10.1038/nature01309.1.

4 Schumacher, K., Cludius, J., ... Van Nuffel, L., 2015. How to end Energy Poverty?

5 Scrutiny of Current EU and Member States Instruments, European Parliament's

6 Committee on Industry, Research and Energy. doi:10.1007/s13398-014-0173-7.2

7 Seneviratne, S.I., Nicholls, N., ... Zwiers, F.W., 2012. Changes in climate extremes

8 and their impacts on the natural physical environment, in: Managing the Risks of

9 Extreme Events and Disasters to Advance Climate Change Adaptation: Special

10 Report of the Intergovernmental Panel on Climate Change. Cambridge University

11 Press, pp. 109-230. doi:10.1017/CBO9781139177245.006

12 Smith, T. B. 2004. Electricity theft: A comparative analysis. Energy Policy, 32(18),

13 2067-2076. https://doi.org/10.1016/S0301-4215(03)00182-4

14 Sovacool, Benjamin K. 2013. Energy and Ethics. Justice and the Global Energy

15 Challenge. Palgrave Macmillan IBSN 978-1-137-29864-5

Steel, L. \& Attala, L., 2019. Body matters: exploring the materiality of the human body.

Stefanizzi, P., Fato, I., Turi, S.D., 2016. Energy and environmental performance of

21 trullo stone building. An experimental and numerical survey. International Journal of Heat and Technology 34, S396-S402. doi:10.18280/ijht.34S229

Tollefson, J., 2010. Drought strikes the Amazon rainforest again. Nature.

Wang, Z., de Dear, R., Luo, M., Lin, B., He, Y., Ghahramani, A., \& Zhu, Y. 2018.

28 Individual difference in thermal comfort: A literature review. Building and Environment. Elsevier Ltd. https://doi.org/10.1016/j.buildenv.2018.04.040

30 WHO. 2004. Heat-waves: risks and responses. Health and Global Environmental

31 Health Series, No.2(2), 124 pp. https://doi.org/10.1007/s00484-009-0283-7 
1 WHO. 2007. Housing, Energy and Thermal Comfort A review of 10 countries within

2 the WHO European Region retrieved from

3 http://www.euro.who.int/_ data/assets/pdf_file/0008/97091/E89887.pdf

4 World Bank. 2015. Brazil: Five things you didn't know about the state of Amazonas.

5 Available Online: https://www.worldbank.org/en/news/feature/2015/03/02/five-

6 things-you-didnt-know-about-amazonas-amazon-brazil

7 World Bank. 2019. Improving Performance of Electricity Distribution in Brazil.

8 Available online: https://www.worldbank.org/en/results/2019/04/24/improving-

9 performance-of-electricity-distribution-in-brazil

10 Zhao, Q., 2019. The association between heatwaves and risk of hospitalization in

11 Brazil: A nationwide time series study between 2000 and 2015. PLoS Medicine 16.

12 doi:10.1371/journal.pmed.1002753

\footnotetext{
${ }^{\mathrm{i}}$ https://www.legifrance.gouv.fr/ Accessed in August 2018

ii https://www.independent.co.uk/environment/climate-change/thousands-of-people-killed-by-extremeweather-so-far-in-2015-as-climate-change-feared-to-bring-more-10345883.html Accessed August 2018 iii Independent.co.uk/environment/climatechange/thousands-of-people-killed-by-extreme-weather-sofar-in-2015-as-climate-change-feared-to-bring-more-103045883.html

iv Light for All programme has invested more than US\$7.1 billion (26 billion R\$, 2018 prices) to reach over 16 million people through more than half a million projects.

v https:/www.ibge.gov.br/geociencias/organizacao-do-territorio/estrutura-territorial/15819-amazonialegal.html?t=0-que-e

vi Based on years 2015-2016 http://pubdocs.worldbank.org/en/444681490076354657/ElectricityTariffs-Power-Outages-and-Firm-Performance.pdf accessed in August 2018
} 